e-Jurnal Ilmiah BIOSAINTROPIS (BIOSCIENCE-TROPIC)

Volume 6/ No.: 2 / Halaman 86 - 95 / Januari Tahun 2021

ISSN : 2460-9455 (e) - 2338-2805(p)

\title{
Perbandingan Kuantitas dan Kualitas DNA Bacillus sp. antara Heat Treatment dan Filter berbasis Kit
}

\section{The Quantity and Quality Comparison of Bacillus sp. DNA between Heat Treatment and Filter Based Kit}

Durrotun Ni'mah ${ }^{1}$, Muhammad Zainul Fadli ${ }^{1}$, Rio Risandiansyah ${ }^{1 *}$

${ }^{1}$ Jurusan Pendidikan Dokter, Fakultas Kedokteran Universitas Islam Malang, Indonesia

\begin{abstract}
ABSTRAK
Penegakkan diagnosis infeksi bakteri dapat dilakukan secara cepat dengan metode isolasi DNA yang telah disederhanakan, seperti Heat Treatment yang merupakan metode ekstraksi DNA sederhana dan ekonomis, namun tingkat deteksi dan kuantifikasi terhadap Bacillus sp. masih belum diketahui. Penelitian ini bertujuan membandingkan kuantitas dan kualitas DNA dari Bacillus sp. dengan menggunakan metode ekstraksi Heat Treatment dan metode isolasi Filter Based Kit. Penelitian ini menggunakan metode penelitian eksperimen secara in vitro. Heat Treatment dibandingkan dengan Filter Based Kit berdasarkan Limit of Detection (LoD) and Limit of Quantification (LoQ). Analisa data menggunakan uji ANOVA serta uji Honesty Significant Diference (HSD). Yield DNA yang didapatkan Heat Treatment pada konsentrasi terbesar adalah $5 \mu \mathrm{g} / \mathrm{ml}$, sedangkan dengan Filter Based Kit adalah $3.67 \mu \mathrm{g} / \mathrm{ml}$. Nilai LoD Heat treatment dan Filter Based Kit adalah $1.61 \mu \mathrm{g} / \mathrm{ml}$ dan $5.72 \mu \mathrm{g} / \mathrm{ml}$, sedangkan nilai LoQ Heat treatment dan Filter Based Kit adalah $4.87 \mu \mathrm{g} / \mathrm{ml}$ dan $17.34 \mu \mathrm{g} / \mathrm{ml}$. Jumlah bakteri yang melebihi nilai LoD dan LoQ Heat treatment adalah $10^{1} \mathrm{CFU} / \mathrm{ml}$ dan $10^{4} \mathrm{CFU} / \mathrm{ml}$, sementara LoD dan LoQ Filter Based Kit adalah $>10^{4} \mathrm{CFU} / \mathrm{ml}$. Kuantitas DNA Bacillus sp. dengan metode Heat Treatment lebih baik dibandingkan dengan Filter Based Kit. Kualitas DNA Bacillus sp. baik dengan metode Heat Treatment maupun Filter Based Kit tidak baik.
\end{abstract}

Kata kunci: isolasi DNA, Bacillus sp., heat treatment, Filter Based Kit

\section{ABSTRACT}

Diagnosis of bacterial infection can be done quickly with simplified DNA isolation methods, such as Heat Treatment, which is a simple and inexpensive DNA isolation method, but detection and quantification levels of Bacillus sp. still unknown. This study aims to compare the quantity and quality of DNA isolates from Bacillus sp. using Heat Treatment etraction method and Filter Based isolation method. This research used in vitro experiment method. Heat Treatment is compared to Filter Based Kit according to Limit of Detection (LoD) and Limit of Quantification (LoQ). Data analyzed with ANOVA and Honesty Significant Difference (HSD). DNA yield obtained by Heat Treatment at the highest concentration was $5 \mu \mathrm{g} / \mathrm{ml}$, whereas Filter Based Kit was 3.67 $\mu \mathrm{g} / \mathrm{ml}$. LoD of the Heat treatment and Filter Based Kit were 1.61 and $5.72 \mu \mathrm{g} / \mathrm{ml}$, while LoQ of the Heat treatment and Filter Based Kit were 4.87 and $17.34 \mu \mathrm{g} / \mathrm{ml}$. The number of bacteria that exceeded the LoD and $\mathrm{LoQ}$ of Heat Treatment was $10^{1}$ and $10^{4} \mathrm{CFU} / \mathrm{ml}$, whereas the LoD and LoQ of Filter Based Kit was $>10^{4}$ CFU/ml. The quantitiy of Bacillus sp. DNA with Heat Treatment method is better than Filter Based Kit. The quality of Bacillus sp. DNA both the Heat Treatment and Filter Based Kit methods are not good.

Keywords: DNA isolation, Bacillus sp., heat treatment, Filter Based Kit

\footnotetext{
*) Rio Risandiansyah, S.Ked., MP., PhD., Jurusan Pendidikan Dokter, FK, Universitas Islam Malang Telp. 081217210321 dan email: riorisandiansyah@unisma.ac.id
}

Makalah Konferensi Nasional KnalSTech Fakultas MIPA Unisma 10 Desember 2020 Dipublikasikan Tanggal 25 Januari 2021 
e-Jurnal Ilmiah BIOSAINTROPIS (BIOSCIENCE-TROPIC)

Volume 6/ No.: 2 / Halaman 86 - 95 / Januari Tahun 2021

ISSN : 2460-9455 (e) - 2338-2805(p)

\section{Pendahuluan}

Saat ini, proses identifikasi bakteri masih membutuhkan waktu yang cukup lama dengan metode konvensional seperti kultur serta uji biokimiawi [1]. Metode-metode tersebut dapat mengidentifikasi bakteri secara umum, namun hasil yang diperoleh seringkali tidak spesifik [2]. Oleh karena itu dibutuhkan metode identifikasi bakteri yang cepat dan tepat seperti Polymerase Chain Reaction (PCR) [3]. PCR merupakan metode yang baik untuk deteksi bakteri karena praktis, sensitif dan spesifik [4].

Isolasi DNA merupakan langkah penting sebelum pelaksanaan PCR. Isolasi DNA dengan metode yang baik dapat menghasilkan DNA yang banyak dengan memaksimalkan kemurnian serta membebaskan DNA dari kontaminan [5]. Tujuan penelitian ini yaitu untuk melihat konsentrasi Bacillus sp. terkecil yang dapat diisolasi dengan metode yang ekonomis serta membutuhkan waktu yang singkat. Oleh karena itu sering dilakukan penyederhanaan metode isolasi DNA. Salah satu bentuk penyederhanaan metode yang akan diteliti adalah metode Heat Treatment (HT). HT merupakan metode ekstraksi DNA melalui boiling dalam water bath atau microwave, sehingga waktu pengerjaan metode ini sangat singkat dan minim biaya [6]. Kuantitas dan kualitas $H T$ dalam memperoleh konsentrasi DNA dibandingkan dengan Filter Based Kit $(F B K)$ yang merupakan metode isolasi DNA yang dikembangkan dari metode silica gel [7]. Metode ini melakukan langkah isolasi DNA berupa ekstraksi, presipitasi dan purifikasi sehingga kemungkinan terjadinya kontaminasi rendah [7]. Metode ini membutuhkan alat tertentu serta langkah pengerjaannya kompleks yang menyebabkan metode ini lama dan kurang ekonomis. Berdasarkan hal itu, peneliti ingin melihat kuantitas dan kualitas DNA dari berbagai konsentrasi dari Bacillus sp. menggunakan metode ekstraksi $H T$ dan metode isolasi $F B K$.

Kualitas dan kuantitas DNA bakteri dapat dilihat berdasarkan hasil kemurnian dan yield [8]. Nilai kemurnian dan yield akan divalidasi dengan menilai Limit of Detection (LoD) dan Limit of Quantification (LoQ) [9]. LoD dan LoQ merupakan parameter standart performa dari sebuah metode analitik [10]. LoD adalah jumlah atau konsentrasi analit terkecil dari sampel yang dapat dibedakan dari blanko [9]. Sedangkan LoQ ialah jumlah analit terendah dalam sampel yang dapat dikuantifikasi [11]. Belum ada penelitian lain yang membahas mengenai perbedaan DNA Bacillus sp. dengan metode $H T$ dan $F B K$. Maka dari itu, penelitian ini akan membandingkan metode $H T$ dan $F B K$ berdasarkan LoD dan LoQ.

\section{Material dan Metode}

\section{Alat dan Bahan}

In vitro Bacillus sp: Sampel Bacillus sp. adalah hasil isolasi yang dilakukan di Laboratorium Mikrobiologi Fakultas Kedokteran UNISMA dan tidak dipublikasikan. Bakteri diidentifikasi secara mikroskopis (Gram positif, berspora) dan morfologi bakteri pada media NA (koloni sirkuler putih).

\section{Metode}

Penelitian ini merupakan penelitian eksperimental laboratorium in vitro dengan desain penelitian analitik kuantitatif. Penelitian dilaksanakan di Laboratorium Mikrobiologi Fakultas Kedokteran UNISMA.

\section{Cara Kerja}

Inokulasi Bacillus sp.: Stok media padat nutrient agar (NA) (komposisi: $0.5 \%$ peptone, $0.3 \%$ ekstrak daging sapi/ekstrak ragi, $1.5 \%$ agar, $0.5 \% \mathrm{NaCl}$, Aquades) yang berisi Bacillus sp. diambil 
e-Jurnal Ilmiah BIOSAINTROPIS (BIOSCIENCE-TROPIC)

Volume 6/ No.: 2 / Halaman 86 - 95 / Januari Tahun 2021

ISSN : 2460-9455 (e) - 2338-2805(p)

dan ditumbuhkan pada stok media cair nutrient broth. Media cair yang sudah keruh, kemudian dibiakkan dalam media padat NA. Oshe digunakan untuk mengambil Bacillus sp. yang telah dibiakkan pada media padat NA. Oshe tersebut dimasukkan ke dalam tabung reaksi yang berisi normal saline (NS) $10 \mathrm{~mL}$, lalu dicampur secara merata.

Kuantifikasi Bacillus sp.: Stok Bacillus sp. diencerkan $10^{-12}$ kali dalam microcentrifuge tube 1,5 ml dan disiapkan satu kontrol yang berisi NS tanpa mengandung bakteri. Metode yang digunakan untuk menghitung bakteri yaitu metode direct count dengan Total Platelet Count (TPC). Bacillus sp. diinokulasi dengan cara menuangkan suspensi bakteri pada media padat NA yang sudah dibagi menjadi 8 bagian (pengenceran $10^{-5}-10^{-12}$ ), kemudian ditetesi Bacillus sp. sesuai dengan tingkat pengencerannya. Media padat diinkubasi dengan suhu $37^{\circ} \mathrm{C}$ selama $18-20$ jam. Setelah diinkubasi, jumlah koloni Bacillus sp. dihitung sesuai letak pembagiannya. Jumlah bakteri sama dengan jumlah koloni dikalikan faktor pengenceran. Selanjutnya, jumlah bakteri dalam plate dengan tiga kali pengulangan di rata-rata. Metode selanjutnya yaitu menggunakan spektrofotometri dengan $\lambda=600$ $\mathrm{nm}$ pada setiap tabung reaksi. Metode ini dilakukan untuk memudahkan pengulangan.

Ekstraksi DNA Bacillus sp. Menggunakan Metode Heat Treatment :Bacillus sp. diambil 5-10 oshe dari stok media padat lalu dipindahkan ke stok media cair yang berisi $10^{5} \mathrm{CFU} / \mathrm{ml}$. Stok tersebut diencerkan hingga $10^{1} \mathrm{CFU} / \mathrm{ml} \mathrm{ke}$ dalam microcentrifuge tube $1.5 \mathrm{ml}$. Stok bakteri dimasukkan ke dalam aquades dengan suhu $100^{\circ} \mathrm{C}$ selama 10 menit kemudian disentrifugasi selama 5 menit dengan kecepatan $1000 \mathrm{rpm}$. Bacillus sp. diberi larutan DNA rehydration solution sebanyak $1 \mathrm{ml}$, kemudian dilakukan pengukuran yield dan kemurnian dengan NanoDrop.

Isolasi DNA Bacillus sp. Menggunakan Metode Filter Based Kit: Bacillus sp. diambil 5-10 oshe dari stok media padat lalu dipindahkan ke stok media cair yang berisi $10^{5} \mathrm{CFU} / \mathrm{ml}$. Stok tersebut diencerkan hingga $10^{1} \mathrm{CFU} / \mathrm{ml} \mathrm{ke}$ dalam microcentrifuge tube $1.5 \mathrm{ml}$. Bakteri disentrifus dengan kecepatan maksimum selama 1 menit dan dibuang supernatannya. Selanjutnya, ditambahkan $100 \mu 1$ EL buffer lalu dicampurkan dengan pellet dan diinkubasi selama $10-60$ menit pada suhu $37^{\circ} \mathrm{C}$. Pellet ditambahkan $100 \mu \mathrm{RS}$ buffer lalu dicampur rata. Kemudian diinkubasi selama 15 menit pada suhu $56^{\circ} \mathrm{C}$ dan ditambahkan $200 \mu \mathrm{l}$ GA buffer serta disentrifus dengan kecepatan $13.000 \mathrm{x}$ g selama 1 menit. Supernatant dipindahkan ke microcentrifuge tube baru yang steril lalu ditambahkan $400 \mu \mathrm{l}$ BA buffer, campur rata. Campuran tersebut dipindahkan ke spin column dan disentrifus dengan kecepatan 13.000 x g selama 1 menit. Larutan G binding buffer sebanyak $500 \mu$ l ditambahkan ke spin colomn lalu disentrifus dengan kecepatan $10.000 \mathrm{x}$ g selama 1 menit. $500 \mu 1$ washing buffer ditambahkan pada spin column dan disentrifus dengan kecepatan $10.000 \mathrm{x}$ g selama 1 menit. Proses tersebut diulangi sebanyak satu kali. Kemudian, $100 \mu$ l elution buffer ditambahkan dan diinkubasi dengan suhu ruangan selama 1 menit. Sampel disentrifus lagi dengan kecepatan 10.000 x g selama 1 menit lalu spin column dilepas dari tube. Microcentrifuge tube tersebut berisi DNA yang telah terfilter. Proses selanjutnya yaitu pengukuran yield dan kemurnian dengan NanoDrop.

Pengukuran Yield dan Kemurnian: Pengukuran yield dan kemurnian hasil isolasi DNA metode $H T$ dan $F B K$ dilakukan dengan NanoDrop pada $\lambda=230,260$ dan $280 \mathrm{~nm}$. Sedangkan hasil kemurnian DNA baik apabila rasio $\mathrm{A}_{260} / \mathrm{A}_{280}$ sebesar 1,8-2,0 [8].

Perhitungan Limit of Detection (LoD) dan Limit of Quantification (LoQ): Perhitungan LoD dan LoQ diperoleh dari standar deviasi respons kurva dan slope kurva kalibrasi sesuai persamaan [12]:

$$
\begin{aligned}
& L o D=3.3(\mathrm{Sy} / \mathrm{S}) \ldots \ldots \ldots \ldots \ldots \ldots \ldots \ldots \ldots \ldots \ldots \ldots \ldots \ldots \ldots \ldots \ldots \ldots \ldots \ldots \ldots \ldots \ldots
\end{aligned}
$$

\section{Keterangan:}

$\mathrm{LoD}=$ Limit of detection

$\mathrm{LoQ}=$ Limit of quantification

$\mathrm{Sy}=$ Standar Deviasi hasil rerata semua sampel

$\mathrm{S}=$ Slope kurva kalibrasi 
e-Jurnal Ilmiah BIOSAINTROPIS (BIOSCIENCE-TROPIC)

Volume 6/ No.: 2 / Halaman 86 - 95 / Januari Tahun 2021

ISSN : 2460-9455 (e) - 2338-2805(p)

Analisis Data: Data yang diperoleh dikonversikan menggunakan software Statistical Product and Service Solutions (SPSS) lalu dilakukan uji parametrik dengan menggunakan uji statistik One Way Analysis of Varians (ANOVA). Kemudian dapat dilakukan uji lanjutan yaitu Post hoc analitic Honesty Significance Different (HSD). Data dinyatakan signifikan jika $p<0.05$.

\section{Hasil dan Diskusi}

\section{Hasil Penelitian}

Kuantifikasi Bacillus sp.: Hasil kuantifikasi Bacillus sp. yang dilakukan dengan metode TPC (Total plate count) dan spektofotometri ditunjukkan pada Tabel 1. Metode TPC dilakukan pada tiga sampel dengan masing-masing pengulangan sebanyak tiga kali. Ketiga ulangan tersebut dilakukan pada faktor pengenceran $10^{-5}$ hingga $10^{-12}$. Selain itu juga dilakukan spektofotometri pada ketiga sampel bakteri.

Hasil TPC sampel Bacillus sp. 1 pada pengenceran $10^{-5}$ diperoleh jumlah bakteri $1.33 \times 10^{5}$ $\mathrm{CFU} / \mathrm{ml}$. Pada sampel Bacillus sp. 1 dan 2 dengan pengenceran $10^{-6}$ hingga $10^{-12}$ tidak ditemukan bakteri viabel. Jumlah bakteri tertinggi sebesar $2 \times 10^{5} \mathrm{CFU} / \mathrm{ml}$ ditemukan pada pengenceran $10^{-5}$ pada sampel Bacillus sp. 2. Hal tersebut dipastikan dengan hasil spektofotometri yaitu sebesar 0.308 nm. Sedangkan jumlah bakteri terendah yaitu $0.67 \times 10^{5} \mathrm{CFU} / \mathrm{ml}$ pada sampel Bacillus sp. 3 yang dibuktikan dengan hasil spektofotometri $0.190 \mathrm{~nm}$. Pada sampel Bacillus sp. 3 masih ditemukan bakteri viabel pada pengenceran $10^{-6}$.

Tabel 1. Hasil Total Plate Count (TPC) dan Spektofotometri Bacillus sp.

\begin{tabular}{ccccccccccc}
\hline $\begin{array}{c}\text { Sampel } \\
\begin{array}{c}\text { Bacillus } \\
\text { sp. }\end{array}\end{array}$ & $10^{-5}$ & $10^{-6}$ & $10^{-7}$ & $10^{-8}$ & $10^{-9}$ & $10^{-10}$ & $10^{-11}$ & $10^{-12}$ & $\begin{array}{c}\text { Jumlah } \\
\text { koloni } \\
\text { bakteri } \\
(\mathrm{CFU} / \mathrm{ml})\end{array}$ & $\begin{array}{c}\text { Absorbansi } \\
(\mathrm{nm})\end{array}$ \\
\hline 1 & 1.33 & 0 & 0 & 0 & 0 & 0 & 0 & 0 & $1.33 \times 10^{5}$ & 0.308 \\
2 & 2 & 0 & 0 & 0 & 0 & 0 & 0 & 0 & $2 \times 10^{5}$ & 0.353 \\
3 & 0.67 & 0.33 & 0 & 0 & 0 & 0 & 0 & 0 & $0.67 \times 10^{5}$ & 0.190 \\
\hline
\end{tabular}

Keterangan: Data sampel Bacillus sp. dinyatakan dalam rata - rata \pm SD dengan $\mathrm{n}=3$

Perbandingan Kuantitas DNA antara Heat Treatment dan Filter Based Kit pada Bacillus sp.: Hasil yield metode $H T$ dan FBK pada Bacillus sp. ditunjukkan pada Tabel 2. Sedangkan perbandingan yield antara metode $H T$ dengan $F B K$ ditunjukkan pada Gambar 1.

Tabel 2. Hasil yield metode HT dan FBK pada Bacillus sp.

\begin{tabular}{ccc}
\hline \multirow{2}{*}{ Konsentrasi $(\mathrm{CFU} / \mathrm{ml})$} & \multicolumn{2}{c}{ Yield $(\mu \mathrm{g} / \mathrm{ml})$} \\
\cline { 2 - 3 } & Heat Treatment & Filter Based Kit \\
\hline Kontrol & $1 \pm 0$ & $2 \pm 0$ \\
$10^{1}$ & $2 \pm 0$ & $4 \pm 1$ \\
$10^{2}$ & $2 \pm 0$ & $3.33 \pm 0.58$ \\
$10^{3}$ & $3.33 \pm 0.58$ & $2.67 \pm 0.58$ \\
$10^{4}$ & $5 \pm 1$ & $3.67 \pm 0.58$ \\
\hline
\end{tabular}

Keterangan: Data yield dinyatakan dalam rata - rata $\pm \mathrm{SD}$ dengan $\mathrm{n}=3$ 
e-Jurnal Ilmiah BIOSAINTROPIS (BIOSCIENCE-TROPIC)

Volume 6/ No.: 2 / Halaman 86 - 95 / Januari Tahun 2021

ISSN : 2460-9455 (e) - 2338-2805(p)

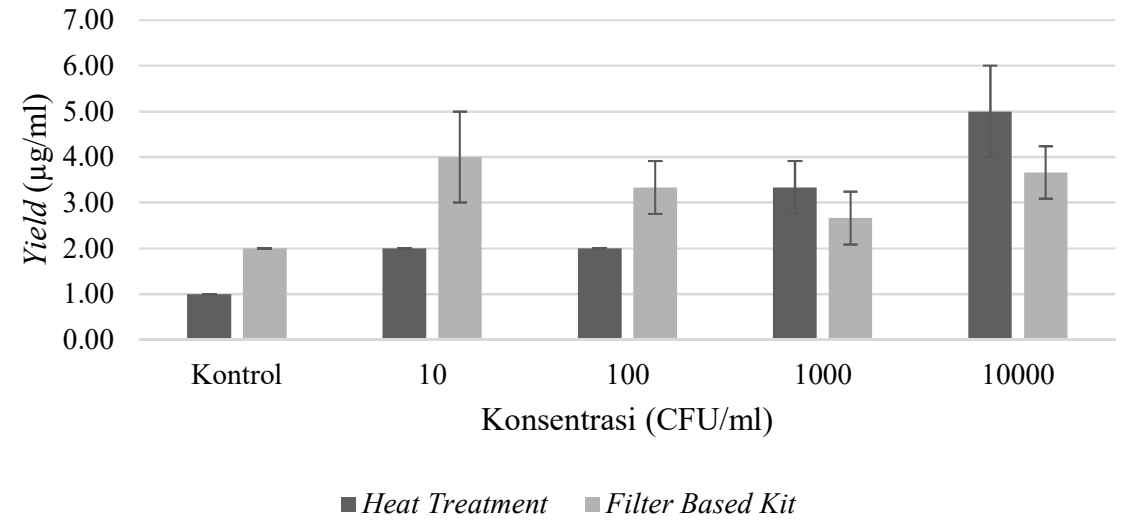

Gambar 1. Grafik Perbandingan yield HT dan FBK

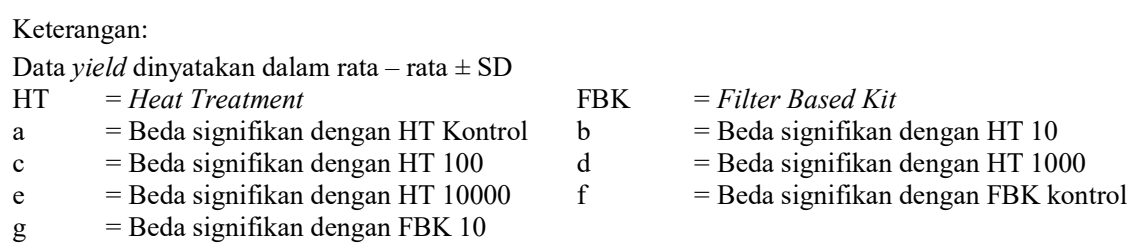

Hasil yield metode $H T$ pada Tabel 2. didapatkan yield tertinggi pada konsentrasi $10^{4} \mathrm{CFU} / \mathrm{ml}$. Sedangkan pada metode $F B K$ hasil yield tertinggi yaitu pada konsentrasi $10^{1} \mathrm{CFU} / \mathrm{ml}$. Pada Gambar 1. yield metode $H T$ sedikit lebih tinggi dibanding yield metode $F B K$. Namun, yield metode $H T$ dan $F B K$ termasuk rendah. Hasil uji statistik perbandingan metode $H T$ dan FBK pada Bacillus sp. pada Gambar 1. menunjukkan berbeda signifikan $(p=0.00)$ antara masing-masing konsentrasi. Uji post hoc HSD diperoleh hasil berbeda signifikan $(p<0.05)$ antara konsentrasi $10^{1} \mathrm{CFU} / \mathrm{ml}$ pada metode $H T$ dan $F B K$.

Uji statistik pada metode $H T$ menunjukkan berbeda signifikan $(p=0.00)$ pada masing-masing konsentrasi. Uji post hoc HSD pada metode $H T$ diperoleh hasil berbeda signifikan $(p<0.05)$ antara kontrol dengan konsentrasi $10^{3} \mathrm{CFU} / \mathrm{ml}$ dan $10^{4} \mathrm{CFU} / \mathrm{ml}$. Pada konsentrasi $10^{1} \mathrm{CFU} / \mathrm{ml}$ berbeda signifikan $(p<0.05)$ dengan konsentrasi $10^{4} \mathrm{CFU} / \mathrm{ml}$. Konsentrasi $10^{2} \mathrm{CFU} / \mathrm{ml}$ diperoleh hasil berbeda signifikan $(p<0.05)$ dengan $10^{4} \mathrm{CFU} / \mathrm{ml}$. Konsentrasi $10^{3} \mathrm{CFU} / \mathrm{ml}$ diperoleh hasil berbeda signifikan $(p<0.05)$ dengan kontrol dan konsentrasi $10^{4} \mathrm{CFU} / \mathrm{ml}$. Konsentrasi $10^{4} \mathrm{CFU} / \mathrm{ml}$ diperoleh hasil berbeda signifikan $(p<0.05)$ dengan kontrol, konsentrasi $10^{1} \mathrm{CFU} / \mathrm{ml}, 10^{2} \mathrm{CFU} / \mathrm{ml}$, dan $10^{3} \mathrm{CFU} / \mathrm{ml}$. Uji statistik pada metode $F B K$ menunjukkan berbeda signifikan $(p=0.02)$ antar masing-masing konsentrasi. Uji post hoc HSD pada metode $F B K$ diperoleh hasil berbeda signifikan $(p<0.05)$ antara kontrol dan konsentrasi $10^{1} \mathrm{CFU} / \mathrm{ml}$.

Perbandingan Kualitas DNA antara Heat Treatment dan Filter Based Kit pada Bacillus sp.: Hasil kemurnian $H T$ dan $F B K$ ditunjukkan pada Tabel 3. Kemurnian metode $H T$ tidak dapat dideteksi pada kontrol, konsentrasi $10^{1} \mathrm{CFU} / \mathrm{ml}, 10^{3} \mathrm{CFU} / \mathrm{ml}$ dan $10^{4} \mathrm{CFU} / \mathrm{ml}$. Pada konsentrasi $10^{2} \mathrm{CFU} / \mathrm{ml}$ diperoleh rata - rata kemurnian $-2 \mu \mathrm{g} / \mathrm{ml}$. Sedangkan kemurnian metode $F B K$ dapat dideteksi pada konsentrasi $10^{1} \mathrm{CFU} / \mathrm{ml}$ dan konsentrasi $10^{3} \mathrm{CFU} / \mathrm{ml}$ dengan rata - rata masing-masing $2.22 \mu \mathrm{g} / \mathrm{ml}$ dan $-0.67 \mu \mathrm{g} / \mathrm{ml}$. Hasil kemurnian dinyatakan baik apabila dalam range $1.8-2.0 \mu \mathrm{g} / \mathrm{ml}$. Sedangkan pada kedua metode tidak mencapai range tersebut maka hasil kemurnian metode $H T$ dan $F B K$ kurang baik. 
e-Jurnal Ilmiah BIOSAINTROPIS (BIOSCIENCE-TROPIC)

Volume 6/ No.: 2 / Halaman 86 - 95 / Januari Tahun 2021

ISSN : 2460-9455 (e) - 2338-2805(p)

Tabel 3. Perbandingan Kemurnian antara HT dengan FBK

\begin{tabular}{ccc}
\hline Konsentrasi & \multicolumn{2}{c}{ Kemurnian $\left(\mathrm{A}_{260} / \mathrm{A}_{280}\right)$} \\
\cline { 2 - 3 }$($ CFU $/ \mathrm{ml})$ & Heat Treatment & Filter Based Kit \\
\hline Kontrol & $n d$ & $n d$ \\
$10^{1}$ & $n d$ & $2.22 \pm 0.69$ \\
$10^{2}$ & $-2 \pm 0$ & $n d$ \\
$10^{3}$ & $n d$ & $-0.67 \pm 3.21$ \\
$10^{4}$ & $n d$ & $n d$ \\
\hline
\end{tabular}

Keterangan:Data dalam rata - rata \pm SD dengan $\mathrm{n}=3 ; N d=$ not detected

Perhitungan LoD dan LoQ Metode Heat Treatment dan Filter Based Kit pada Bacillus sp.: Hasil perhitungan LoD dan LoQ terhadap metode $H T$ dan $F B K$ ditunjukkan pada Tabel 4. Nilai LoD metode $H T$ ialah $1.61 \mu \mathrm{g} / \mathrm{ml}$, sedangkan nilai LoQ ialah $4.87 \mu \mathrm{g} / \mathrm{ml}$. Hasil LoD metode $H T$ diperoleh dari $3.3 \times(0.46 / 0.94)$, sementara hasil LoQ diperoleh dari $10 \times(0.46 / 0.94)$. Pada metode $F B K$ nilai LoD ialah $5.72 \mu \mathrm{g} / \mathrm{ml}$, sedangkan nilai LoQ ialah $17.34 \mu \mathrm{g} / \mathrm{ml}$. Perhitungan LoD metode $F B K$ berasal dari hasil $3.3 \times(0.36 / 0.21)$ dan LoQ berasal dari hasil $10 \times(0.36 / 0.21)$.

Tabel 4. Nilai LoD dan LoQ metode HT dan FBK pada Bacillus sp.

\begin{tabular}{ccccc}
\hline Metode isolasi & \multicolumn{2}{c}{ LoD } & \multicolumn{2}{c}{ LoQ } \\
\cline { 2 - 5 } DNA & Rumus & Hasil $(\mu \mathrm{g} / \mathrm{ml})$ & Rumus & Hasil $(\mu \mathrm{g} / \mathrm{ml})$ \\
\hline$H T$ & $3.3(\mathrm{Sy} / \mathrm{S})$ & 1.61 & $10(\mathrm{Sy} / \mathrm{S})$ & 4.87 \\
$F B K$ & & 5.72 & & 17.34 \\
\hline
\end{tabular}

Keterangan: $\mathrm{Sy}=$ Standar deviasi rerata semua sampel $; \mathrm{S}=$ Slope kurva kalibrasi

\section{Pembahasan}

Kuantifikasi Bacillus sp.: Kuantifikasi Bacillus sp. dilakukan dengan metode direct count. Metode direct count menggunakan Total Plate Count (TPC) bertujuan untuk mengetahui jumlah koloni bakteri yang viabel [13]. Proses TPC diawali dengan pengenceran serial yang bertujuan untuk mendapatkan koloni dalam range 30-300 CFU/ml [13]. TPC melibatkan beberapa pengenceran dalam kelipatan 10. Jumlah pengenceran dipilih berdasarkan perkiraan awal kepadatan kultur [13]. Pengenceran serial pada penelitian ini dilakukan pada faktor pengenceran $10^{-1}$ sampai dengan $10^{-12}$.

Jumlah koloni yang dapat dihitung dengan reliable adalah antara 30-300 koloni bakteri [13]. Standart nilai TPC ialah tidak lebih dari $300 \times 10^{5} \mathrm{CFU} / \mathrm{ml}$ " [13]. Hasil dinyatakan To Numerous to Count (TNTC) apabila didapatkan lebih dari 300 koloni" [14]. Jumlah koloni kurang dari 30 menandakan bahwa koloni bakteri terlalu sedikit dan tidak representatif [14]. Pengenceran $10^{-1}$ sampai dengan $10^{-4}$ dapat menghasilkan TNTC yang akan menyulitkan perhitungan koloni secara akurat. Sehingga pada penelitian ini, TPC dilakukan pada faktor pengenceran $10^{-5}$ hingga $10^{-12}$. Hasil estimasi jumlah bakteri yang diperoleh pada kelompok 1, 2 dan 3 secara berurutan adalah 1.33 x $10^{5} \mathrm{CFU} / \mathrm{ml}, 2 \times 10^{5} \mathrm{CFU} / \mathrm{ml}$ dan $0.67 \times 10^{5} \mathrm{CFU} / \mathrm{ml}$. Pada Tabel 1 . menunjukkan bahwa ketiga sampel menghasilkan jumlah koloni yang sedikit $(<30$ koloni). Hasil yang terlalu sedikit bisa disebabkan karena kurangnya pencampuran sampel secara menyeluruh saat proses pengenceran serial sehingga distribusi bakteri kurang menyeluruh [13]. 
e-Jurnal Ilmiah BIOSAINTROPIS (BIOSCIENCE-TROPIC)

Volume 6/ No.: 2 / Halaman 86 - 95 / Januari Tahun 2021

ISSN : 2460-9455 (e) - 2338-2805(p)

Kuantitas dan Kualitas DNA dari Bacillus sp. pada Beberapa Konsentrasi dengan Metode Heat

Treatment: Keberhasilan isolasi DNA dapat dilihat dari kuantitas dan kualitasnya. Kuantitas DNA dapat dilihat berdasarkan hasil yield yang diperoleh dari NanoDrop. Yield ditunjukkan dengan concentration dalam NanoDrop. Prinsip NanoDrop ialah mengukur sinar UV pada $\mathrm{A}_{260}$ yang diserap oleh DNA dan $\mathrm{A}_{280}$ yang diserap oleh protein [7]. Pengukuran yield bertujuan untuk mengetahui taksiran jumlah DNA bakteri yang terkandung dalam sampel [15]. Concentration $(\mu \mathrm{g} / \mathrm{ml})$ dapat diperoleh dari absorbansi pada $\mathrm{A}_{260}$ dikali faktor $\mathrm{C}(50 \mu \mathrm{g} / \mathrm{ml}=$ konversi unit dari double-helix DNA) dikali faktor dilusi [16]. Absorbansi 260 secara tidak langsung dapat menggambarkan konsentrasi DNA. Pembacaan $\mathrm{A}_{260}$ dinyatakan valid apabila berada pada range 0.1 - 0.5. Pembacaan diluar range tersebut tidak mencerminkan konsentrasi DNA [17].

$H T$ melakukan proses esktraksi yang dilakukan dengan memanaskan sampel pada suhu $100^{\circ} \mathrm{C}$ selama 10 menit, sehingga waktu pengerjaannya singkat [16]. Selain itu, $H T$ tidak membutuhkan reagen kimia atau instrumen yang banyak sehingga biaya yang dibutuhkan minimal. Pada Tabel 2. hasil yield metode $H T$ berkisar antara $1-5 \mu \mathrm{g} / \mathrm{ml}$. Pada data tersebut, yield metode $H T$ terbilang rendah karena concentration dinyatakan tinggi apabila lebih dari $10 \mu \mathrm{g} / \mathrm{ml}$. Rendahnya yield metode $H T$ karena jumlah bakteri yang sedikit. Nilai LoD metode $H T$ ialah $1.61 \mu \mathrm{g} / \mathrm{ml}$ yang berarti dengan konsentrasi $10^{1} \mathrm{CFU} / \mathrm{ml}$ sampel sudah dapat dideteksi. Sedangkan nilai LoQ metode $H T$ ialah 4.87 $\mu \mathrm{g} / \mathrm{ml}$ yang berarti membutuhkan konsentrasi $10^{4} \mathrm{CFU} / \mathrm{ml}$ untuk bakteri dapat dikuantifikasi. Hal tersebut sesuai dengan hipotesis penelitian sehingga metode $H T$ dapat dijadikan alternatif dalam memperoleh konsentrasi DNA Bacillus sp.. HT merupakan metode yang lebih cepat, sederhana dan efektif daripada metode $F B K$ [18]. Selain itu, metode $H T$ lebih baik dari segi biaya, sedikitnya langkah yang dibutuhkan, waktu pelaksanaan serta hasil DNA.

Hasil konsentrasi DNA Bacillus sp. selanjutnya dilakukan pengamatan kualitas DNA bakteri. Kualitas DNA bakteri dapat diperoleh dari hasil kemurnian sampel. Kemurnian diukur menggunakan NanoDrop yang ditunjukkan dengan perbandingan absorbansi $260 \mathrm{~nm}$ dengan $280 \mathrm{~nm}$ [7]. Hasil dikatakan murni apabila rasio perbandingan $\mathrm{A}_{260} / \mathrm{A}_{280}$ adalah $1.8-2.0 \mu \mathrm{g} / \mathrm{ml}$ [22]. Pada penelitian ini diperoleh kemurnian $-2 \mu \mathrm{g} / \mathrm{ml}$ pada konsentrasi $10^{2} \mathrm{CFU} / \mathrm{ml}$ pada metode $H T$. Hasil kemurnian dibawah $1.8 \mu \mathrm{g} / \mathrm{ml}$ menujukkan bahwa selama proses isolasi DNA, protein, karbohidrat dan lipid tidak dapat dihilangkan secara sempurna [20]. Hal ini bisa disebabkan karena $H T$ hanya melakukan proses ekstraksi saja tanpa melalui proses presipitasi dan purifikasi [1]. Sehingga metode $H T$ berpotensi masih didapatkan makromolekul lain seperti protein, karbohidrat, dan lipid [21]. Kemurnian yang rendah juga disebabkan oleh konsentrasi bakteri yang rendah sehingga protein dan RNA kontaminan juga rendah yang mengakibatkan angka tidak terbaca.

Kuantitas dan Kualitas DNA dari Bacillus sp. pada Beberapa Konsentrasi dengan Metode Filter Based Kit: Isolasi DNA dengan FBK (Bioflux DNA extraction kit) menggunakan teknologi silica-gelmembrane dan spin column [20]. Metode FBK sebagai representasi metode konvensional karena FBK melakukan proses ekstraksi, presipitasi dan purifikasi dengan langkah yang lebih sederhana [22]. Kuantitas dan kualitas DNA Bacillus sp. ditentukan oleh hasil yield dan kemurnian pada berbagai konsentrasi bakteri. Pada Tabel 2. hasil rerata yield metode $F B K$ pada sampel kontrol $2 \mu \mathrm{g} / \mathrm{ml}$, konsentrasi $10^{1} \mathrm{CFU} / \mathrm{ml} 4 \mu \mathrm{g} / \mathrm{ml}, 10^{2} \mathrm{CFU} / \mathrm{ml} 3.33 \mu \mathrm{g} / \mathrm{ml}, 10^{3} \mathrm{CFU} / \mathrm{ml} 2.67 \mu \mathrm{g} / \mathrm{ml}$, dan $10^{4} \mathrm{CFU} / \mathrm{ml}$ $3.67 \mu \mathrm{g} / \mathrm{ml}$. Berdasarkan data tersebut yield metode $F B K$ tergolong rendah. Hal tersebut dapat disebabkan karena jumlah bakteri yang sedikit. Selain itu, sitosol bakteri mungkin masih utuh sehingga menghasilkan sampel yang memiliki yield rendah [18]. Adapun rendahnya yield dapat disebabkan karena jumlah bakteri rekomendasi dari Bioflux kit ialah $10^{7}-10^{9} \mathrm{CFU} / \mathrm{ml}$ untuk mendapatkan hasil yang optimal [19]. Sedangkan pada penelitian ini jumlah bakteri yang digunakan ialah $10^{5} \mathrm{CFU} / \mathrm{ml}$ yang relatif lebih rendah dibanding dengan rekomendasi kit. Di sisi lain, langkah dalam metode FBK melibatkan manipulasi multi-step yang dapat mempengaruhi yield DNA [18]. Langkah yang banyak dan kompleks meningkatkan potensi yield yang diperoleh kurang maksimal [18].

Nilai LoD metode $F B K$ ialah $5.72 \mu \mathrm{g} / \mathrm{ml}$ dan nilai LoQ ialah $17.34 \mu \mathrm{g} / \mathrm{ml}$. Hal tersebut menunjukkan bahwa membutuhkan konsentrasi bakteri diatas $10^{4} \mathrm{CFU} / \mathrm{ml}$ untuk dapat dideteksi dan 
e-Jurnal Ilmiah BIOSAINTROPIS (BIOSCIENCE-TROPIC)

Volume 6/ No.: 2 / Halaman 86 - 95 / Januari Tahun 2021

ISSN : 2460-9455 (e) - 2338-2805(p)

dikuantifikasi. Hal yang menyebabkan hasil $F B K$ tidak lebih rendah dari $H T$ ialah faktor bakteri serta cara kerja kit. FBK merupakan metode yang dikembangkan dari metode silica-gel atau glass beads sehingga menghasilkan metode silica membrane spin column. Prinsip silica membrane spin column ialah memiliki afinitas tinggi terhadap senyawa negatif DNA yang diikat pada senyawa positif silica particles [24]. DNA diikat oleh silica particles dengan erat lalu washing buffer akan menghilangkan semua kontaminan lewat membrane [25]. Kekurangan membran silica adalah ketidakmampuannya untuk mempurifikasi DNA dengan adanya senyawa phenolic dan substansi humic [9]. Senyawa ini merupakan senyawa negatif sehingga dapat berikatan dengan membrane silica yang seharusnya mengikat DNA saja [9]. Beberapa spesies Bacillus sp. dapat menghasilkan enzim tyrosinase yang berkontribusi dalam meningkatkan substansi humic [26]. Oleh karena itu, tanpa dilakukannya penghilangan senyawa phenolic dan substansi humic pada Bacillus sp. maka hasil isolasi DNA FBK kurang maksimal.

Pada metode $F B K$ diperoleh kemurnian antara $-0.67 \mu \mathrm{g} / \mathrm{ml}$ hingga $2.22 \mu \mathrm{g} / \mathrm{ml}$ serta ada beberapa yang tidak terdeteksi. Rasio kemurnian dibawah $1.8 \mu \mathrm{g} / \mathrm{ml}$ atau diatas $2.0 \mu \mathrm{g} / \mathrm{ml}$ menunjukkan bahwa adanya kontaminasi RNA, wash solution, ethanol atau protein [15]. Adanya kontaminasi ethanol bisa disebabkan karena proses purifikasi yang kurang sempurna [19]. Adapun kontaminan RNA dapat disebabkan karena kurang maksimalnya kerja RNAse [15]. Proteinase K berfungsi untuk melisiskan protein-protein dalam sel bakteri, namun pada kit ini tidak didapatkan Proteinase K solution, sehingga dapat mempengaruhi hasil yield dan kemurnian sampel [23]. Metode ini juga melakukan langkah yang banyak meliputi penggantian $4-6$ microcentifuge tube, beberapa tahap inkubasi, presipitasi, elusi, pencucian dan pengeringan atau membutuhkan peralatan khusus. Hal tersebut dapat menyebabkan hasil kemurnian yang buruk [18].

\section{Kesimpulan}

Berdasarkan hasil analisa data serta pembahasan pada penelitian ini dapat disimpulkan bahwa kuantitas DNA Bacillus sp. metode ekstraksi $H T$ lebih tinggi dibanding metode isolasi FBK. Hal tersebut dapat dilihat dari hasil konsentrasi minimum metode $H T$ agar Bacillus sp. dapat terdeteksi dan terkuantifikasi ialah $10^{1} \mathrm{CFU} / \mathrm{ml}$ dan $10^{4} \mathrm{CFU} / \mathrm{ml}$. Sedangkan konsentrasi minimum metode FBK agar Bacillus sp. dapat terdeteksi dan terkuantifikasi ialah diatas $10^{4} \mathrm{CFU} / \mathrm{ml}$. Kualitas DNA Bacillus sp. metode ekstraksi $H T$ dan metode isolasi $F B K$ diluar range kemurnian yang baik yaitu berkisar antara $1.8-2.0 \mu \mathrm{g} / \mathrm{ml}$.

\section{Ucapan Terima kasih}

Terima kasih disampaikan kepada IOM (Ikatan Orangtua Mahasiswa) yang telah menyediakan pembiayaan untuk melakukan penelitian.

\section{Daftar Pustaka}

[1] Lu Z, Guo W, Liu C. 2018. Isolation, identification, and characterization of novel Bacillus subtilis. Journal of Veterinary Medical Science.16-0572.

[2] Ping DY, Chao XZ, Lian YG, Wei L, Feng ZQ, Hong YD, Jie L, Li C, Yun Z, Yi XC. 2019. A newly isolated Bacillus subtilis strain named WS-1 inhibited diarrhea and death caused by pathogenic Escherichia coli in newborn piglets. Frontiers in Microbiology. 10:1248.

[3] Muthén LK, Muthen B. 2017. Mplus user's guide: Statistical analysis with latent variables, user's guide. Muthén \& Muthén;

[4] Gupta N. 2019. DNA extraction and polymerase chain reaction. Journal of cytology. 36(2):1167. 
e-Jurnal Ilmiah BIOSAINTROPIS (BIOSCIENCE-TROPIC)

Volume 6/ No.: 2 / Halaman 86 - 95 / Januari Tahun 2021

ISSN : 2460-9455 (e) - 2338-2805(p)

[5] Boesenberg-Smith KA, Pessarakli MM, Wolk DM. 2012 Assessment of DNA yield and purity: an overlooked detail of PCR troubleshooting. Clinical Microbiology Newsletter. 34(1):1-6.

[6] Mulyani Y, Purwanto A, Nurruhwati I. 2011. Perbandingan beberapa metode isolasi DNA untuk deteksi dini koi herpes virus (KHV) pada ikan mas (Cyprinus carpio L.). Jurnal Akuatika. 2(1).

[7] Berensmeier S. 2006. Magnetic particles for the separation and purification of nucleic acids. Applied microbiology and biotechnology. 73(3):495-504.

[8] Syafaruddin S, Randriani E, Santoso TJ. 2011. Efektivitas dan efisiensi teknik isolasi dan purifikasi DNA pada jambu mete. Journal of Industrial and Beverage Crops. 2(2):141601.

[9] Currie LA. 1995. Nomenclature in evaluation of analytical methods including detection and quantification capabilities (IUPAC Recommendations 1995). Pure and applied chemistry. 67(10):1699-723.

[10] Nutz S, Döll K, Karlovsky P. 2011. Determination of the LOQ in real-time PCR by receiver operating characteristic curve analysis: application to qPCR assays for Fusarium verticillioides and F. proliferatum. Analytical and bioanalytical chemistry. 401(2):717-26.

[11] Munch DJ, Wasko M, Flynt E, Wendelken SC, Scifres J, Mario JR, Hunt M, Gregg D, Schaeffer T, Clarage M, Lumpkin MS. Validation and Peer Review of US Environmental Protection Agency Chemical Methods of Analysis.

[12] Sains P. $n d$. Validasi Metode Untuk Analisis Kandungan Uranium Menggunakan Potensiometer T-90. Metode.;3:4.

[13] Food and Drug Administration. Bacteriological analytical manual. revision A.

[14] Mayanti B, Ariesyady H. 2009. Identifikasi Keberagaman Bakteri pada Commercial-Seed Pengolah Limbah Cair Cat. Jurnal Teknik Lingkungan. 16(1):52-61.

[15] Murtiyaningsih H. 2017. Isolasi DNA genom dan identifikasi kekerabatan genetik nanas menggunakan RAPD (Random Amplified Polimorfic DNA). Agritrop: Jurnal Ilmu-Ilmu Pertanian (Journal of Agricultural Science). 15(1).

[16] Mulyatni AS, Budiani A, Taniwiryono D. nd. Aktivitas antibakteri ekstrak kulit buah kakao (Theobroma cacao L.) terhadap Escherichia coli, Bacillus subtilis, dan Staphylococcus aureus. E-Journal Menara Perkebunan. 80(2).

[17] BIOL 3716: Molecular Biology I. Protocol: Spectrophotometric Determination of DNA Quantity and Purity. Genetics \& Biotechnology Lab. v091708. Diterima Tanggal 23 Agustus 2020.

URL: http://crcooper01.people.ysu.edu/3716-Determining\%20DNA\%20Conc-F08.pdf

[18] Ahmed OB, Asghar AH, Elhassan MM. 2014. Comparison of three DNA extraction methods for polymerase chain reaction (PCR) analysis of bacterial genomic DNA. African Journal of Microbiology Research. 8(6):598-602.

[19] Hidayani AA, Tassakka AC, Parenrengi A. 2016. Isolation and characterization of an envelope protein (VP19) of a White Spot Syndrome Virus from diseased vannamei (Litopenaeus vannamei) in Indonesia. Aquaculture, Aquarium, Conservation \& Legislation. 9(2):389-95.

[20] Riahi M, Babaei M, Ghahremaninejad F. 2019. Genomic DNA Isolation From Scrophularieae Dried Leaves Using A Simple, High-Throughput Protocol. Bangladesh Journal Of Botany. 48(4):1231-5.

[21] Safitri R, Muchlissin SI, Mukaromah AH, Darmawati S, Ethica SN. 2018. Isolasi Bakteri Penghasil Enzim Protease Bacillus Thuringiensis Irodi Pada Oncom Merah Pasca Fermentasi 24 Jam. InProsiding Seminar Nasional \& Internasional (Vol. 1, No. 1).

[22] Shi R, Lewis RS, Panthee DR. 2018. Filter paper-based spin column method for cost-efficient DNA or RNA purification. Plos one. 13(12): $\mathrm{e} 0203011$.

[23] Cheng HR, Jiang N. 2006. Extremely rapid extraction of DNA from bacteria and yeasts. Biotechnology letters 28(1):55-9. 
e-Jurnal Ilmiah BIOSAINTROPIS (BIOSCIENCE-TROPIC)

Volume 6/ No.: 2 / Halaman 86 - 95 / Januari Tahun 2021

ISSN : 2460-9455 (e) - 2338-2805(p)

[24] Esser KH, Marx WH, Lisowsky T. 2006. maxXbond: first regeneration system for DNA binding silica matrices. Nature methods. 3(1):i-i.

[25] Melzak KA, Sherwood CS, Turner RF, Haynes CA. 1996. Driving forces for DNA adsorption to silica in perchlorate solutions. Journal of colloid and interface science. 181(2):635-44.

[26] Radji M. 2006. Penuntun Praktikum Mikrobiologi Farmasi. Edisi ke 2. Departemen Farmasi FMIPA-UI. hal15-43. 